\title{
Mobbing from the Standpoint of Symbolic Interactionism
}

\author{
Piotr A. Chomczyński \\ University of Lodz, Poland
}

DOI: http://dx.doi.org/10.18778/1733-8077.16.4.04

Keywords:

Mobbing;

Qualitative

Research; Deviance

\begin{abstract}
Mobbing at the workplace assumes strong, intensive, and significant interactions between an offender and a target, or a group of targets, causing serious damage to work efficiency, atmosphere, motivation, and employee fluctuation. It also highly affects the victims' mental health, which often results in excluding them from work for a long time.
\end{abstract}

The objective of this paper is to examine the issue of mobbing from the perspective of symbolic interactionism (SI) that is useful in explaining social phenomena on a micro and mezzo level. Through inductive reasoning with the use of grounded theory (GT), I focus on the narratives of mobbing targets and their stories concerning maltreatment at the workplace. The study based on a qualitative approach included 72 narrative interviews carried out among harassment victims, as well as 12 in-depth interviews with professionals dealing with the matter of mobbing. Moreover, to directly follow work-related processes linked to organizational behavior, I utilized participant observation.
Piotr A. Chomczyński, employed by the Department of Sociology of Organization and Management, Faculty of Economics and Sociology, University of Lodz whose areas of scientific interest include: qualitative sociology, symbolic interactionism, and the sociology of deviance.

email address: piotr.chomczynski@uni.lodz.pl

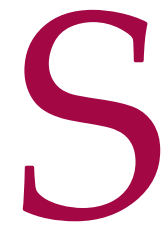
everal decades ago symbolic interactionism (SI) gave birth to a fresh new look at human relations and offered methods enabling to describe them on a micro-level. The Chicago School representatives, later theoreticians and scholars, developed SI to depict symbolic interaction(s) based on the significant gestures, 
definitions of situations, and meanings that social actors produce during their daily activities. Herbert Blumer (1969:1) defines SI "as a label for a relatively distinctive approach for the study of human group and human conduct." At the center of analysis, there is symbolic communication, producing meanings through interactions, interpreting, and defining the situations by social actors. SI allows us to follow group processes and their dynamics that are based on social actors' interplay.

I find SI to be both a fruitful and useful perspective to examine human professional interchange at the workplace, where people communicate with each other on an ongoing basis using verbal and nonverbal gestures. The issue of mobbing gives a perfect opportunity to employ interactionist conceptualizations of power and control relations (Prus 1999) between two parties: a mobber and a target. As my analytical and theoretical frame, SI inclined me to raise some questions about the interactional context of mobbing. My findings deliver answers to the following questions: How a target becomes a victim? What role do joint action and collectivism play in the escalation of mobbing? What are the dynamics of mobbing as a social process?

This article is a continuation of my research on mobbing that took place between 2005-2008. Since that time I have carried out 6 interviews with targets and 2 interviews with mobbers. The last ones have been more focused on the interactional aspects of physical harassment at the workplace, contributing to the use of a symbolic frame to contextualize my analyses.

\section{Symbolic Interactionism as the Theoretical Perspective}

George Herbert Mead laid the foundations for future SI (Blumer 1966; 1969). He opted for an inter- pretative perspective as opposed to normative and positivistic paradigms (Wilson 1970; Konecki 2017; Woroniecka 2017). It was based on the Chicago School heritage (Konecki and Chomczyński 2012) and the conception of not-determined human beings who give meanings due to the interpretation of gestures (Mead 1934:80). Mead was not alone in advocating for an indeterministic conception of human beings as reflexive entities equipped with consciousness, mind, and selves. Charles Horton Cooley (1922), William James (1950), and many others also shared the vision of human beings as the ones of "free will." In opposition to traditional assumptions, Mead stated that "human beings possess minds and consciousness as original 'givens,' that they live in worlds of pre-existing and self-constituted objects, that their behavior consists of responses to such objects, and that group life consists of the association of such reacting human organisms" (Blumer 1966:535; see also: Gusfield 2003:121). It should be stressed that behind social actors' actions towards things there are meanings that they give and produce through social interactions (Blumer 1969:77-78). As human beings do not possess a predefined set of meanings, they construct them instead in the course of dynamic interpretation processes whereby they produce specific definitions of what they encounter. Bryant, Buttigieg, and Hanley (no date) advocate that SI perspective is useful in workplace violence research as it locates the definition of the situation at the center of attention, "Individuals derive their own meanings from situations like workplace bullying, which are likely to differ substantially from meanings developed by others." SI is a coherent theoretical (Hałas 1994; Czekaj 2007; Chomczyński 2017) and methodological (Hałas 1990; Woroniecka 2017) approach enabling the understanding of everyday life and the realities that people create therein. For that reason, SI seems to be an adequate perspective when studying 
unethical symbolic communication aimed at discrediting people in the workplace environment in an unobtrusive way. Mobbing is the process of dynamic interaction between offender(s) and victim(s) that "involves acts of interpersonal aggression-any form of behavior directed towards the goal of harming or injuring another living being who is motivated to avoid such treatment" (Neuman and Baron 2003:185). Physical harassment is based on hostile actions, very often taking the form of nuances that a target defines as unwanted and hostile (Bryant and Cox 2003). Looking at mobbing through the SI prism gives a researcher a strong analytical tool needed for deepening one's micro perspective insight (Piotrowski 1985:29; Klunklin and Greenwood 2006:3334). SI is useful to understand the biographical experiences of people involved in in-group processes (Blumer 1969:6; Denzin 1978), giving them meanings (Mead 1934:80; Prus and Grills 2003:19), and producing definitions of situations they are immersed in (Konecki 2005a; 2005b).

\section{Gaps in the Literature}

Soon after a Swedish psychologist, Heinz Leymann, published his first findings in the area at hand, mobbing has been defined in the 1970s in the field of management in terms of "pathology." Social scientists adapted his operational definition of mobbing and made use of it, as the practitioners did, to diagnose the first "victims":

Psychological terror or mobbing in working life involves hostile and unethical communication, which is directed in a systematic way by one or a few individuals mainly towards one individual who, due to mobbing, is pushed into a helpless and defenseless position, being held there by means of continuing mobbing activities. [Leymann 1996:168]
According to the Sixth European Working Conditions Survey (2015) published by the European Foundation for the Improvement of Living and Working Conditions, $17 \%$ of women and $15 \%$ of men report having been exposed to bullying or harassment in the last 12 months. ${ }^{1}$ Previously, European social partners signed a Framework Agreement on harassment and violence at work. In addition, mental health at the workplace is promoted in the European Strategy on Health and Safety (2007-2013). ${ }^{2}$

Since the first research in the late 1970s and 1980s, the issue of mobbing gained popularity and social scientists started doing cross-country surveys to compare and diagnose the working conditions (Jacobson, Hood, and Van Buren 2014; Salin et al. 2018). The literature on mobbing emphasizes mental health considerations (Leymann 1996; Anderson 2002; Hallberg and Strandmark 2006), as well as management (Zapf, Knorz, and Kulla 1996; Hoel, Faragher, and Cooper 2004; Godlewska-Werner 2006) and business (Niedl 1996; Hoel 2004) perspectives. It is based on the socalled "objective indicators" that illustrate the consequences of mobbing at the micro, mezzo, and macro levels. The majority of such research uses questionnaires and psychological tests. It also provides comparable statistics showing the scale and range of violence in the workplace. However, very few researchers adapted a qualitative approach to reflect the targets' definitions of the situation. Edvin Lemert (1962) employed SI to show how communication issues at the workplace are socially constructed. Sarah J. Tracy, Pamela Lutgen-Sandvik, and Jess Alberts (2006:148) used a victim's "metaphor analysis to articulate and explore the emotional pain of workplace bullying."

\footnotetext{
${ }^{1}$ See: https://www.eurofound.europa.eu/surveys/european-working-conditions-surveys/sixth-european-working-conditions-survey-2015. Retrieved September 17, 2020.

${ }^{2}$ See: https://www.eurofound.europa.eu. Retrieved March 21, 2019.
} 
Also, very few researchers opted for the qualitative perspective of mobbing. Robert Thornberg and Hanna Delby (2019) used the SI frame for in-depth research on the students' perception of school bullying. Auguste, Briggs, and Vreeland (2014) also used SI for micro-level studies of bullying in educational settings. In his studies on status, conflict, and asymmetric relations, Lonnie Athens (2017) applied radical interactionism that places the utmost importance on dominance and power. Still, from my standpoint, there is a scarcity of qualitative, interviewee-oriented research on work-related violence. For that reason, to explore the participants' personal experiences of work-related harassment, I shifted my interest from what happened to what meaning employees attach to their experiences (Czarniawska 2007). The process of becoming a target, variations of the definitions of the situation, target-offender mutual interplay, and symbolic interactions are rarely at the center of scientific investigations. Thus, in this paper, I employ grounded theory (GT) (Glaser and Strauss 1967; Strauss 1987; Strauss and Corbin 1990) and SI (Blumer 1969) to shed light on the nuances of workplace harassment.

\section{Methodology and Research Settings}

SI provides both theoretical frames and methodological premises placing the empirical world, people under study, and their experiences at the center of a researcher's concern. "Nothing is known of human beings except in the form of something that they indicate or refer to. To indicate anything, human beings must see it from their perspective; they must depict it as it appears to them" (Blumer 1969:22). SI emphasizes the primacy of reality under study over the methodology applied. Blumer argued that theory should follow the research and not the other way around (Hałas 1994:49; Woroniecka 2017:56-57), and the methodological stance of SI is that of immediate examination of the empirical social world (Klunklin and Greenwood 2006:34).

GT as the theoretical and methodological perspective, especially its version by Juliet Corbin and Anselm Strauss (2008) displays significant similarities to SI, having strong roots in pragmatism. Chamberlain-Salaun, Mills, and Usher (2013:2) directly point out its SI underpinning in terms of assumptions:

Corbin and Strauss' (2008) "lost chapter" and the 16 assumptions introduce the reader to essential grounded theory methods, and provide a background to the development of pragmatism and symbolic interactionism as the epistemological and ontological foundations of evolved grounded theory.... as the interpretation of works by John Dewey, George Herbert Mead, Herbert Blumer, and Anselm Strauss himself.

For that reason it was a good fit to employ GT for data gathering, analyzing, and generating categories (Glaser and Strauss 1967; Strauss and Corbin 1990; Konecki 2000:32-47; 2015:25-28). The reasoning based on the inductive approach gave me a chance to progressively depict the complex picture of interactions underlying mobbing practices at the workplace. Kathy Charmaz (2014:65) advocates the benefits of GT-based research framed by SI background as providing theoretical sensitivity for data analyses. "The codes that arose from symbolic interactionist sensibilities give a theoretical foundation or conceptual infrastructure that integrates the narrative" (Charmaz 2014:154).

Mobbing belongs to the sphere of pathologies in organizational management (Chomczyński 2008), and as a researched phenomenon requires a methodological approach that would locate the perspectives of people involved at the center of scientific inquiry. Their narrations and definitions of situations 
allow us to understand what meanings they give to workplace harassment, actions of the offender(s), and the contexts' dynamism. Insight into the social actors' biographies was crucial enough to employ narrative interviews as the key research technique. This technique allowed interviewees to construct their stories openly (Jovchelovitch and Bauer 2000). It facilitated a spontaneous discussion of their trauma experiences and the conditions under which it occurred (Loch 2008). People under study were informed that they can withdraw from the research at any time; they were familiar with the methodology, goals, and research objectives of the study.

The study draws on 72 narrative interviews carried out with the targets of workplace mobbing. Both men and women were recruited via snowball sampling-a method typical for ethnographic and exploratory research (Biernacki and Waldorf 1981; Çelik and Lüküslü 2012; Gobo and Molle 2017; Wojciechowska 2018), and with the help of the anti-mobbing foundation in Poland ("Dignity"). Interviews with specialists (12) were more structured and aimed at seeking concrete information from their professional point of view. Additionally, in 2006, I got hired for 1,5 months in a company accused of mobbing, where I carried out participant observations (Chomczyński 2006). This experience enabled me to gain firsthand knowledge from the standpoint of a low-level physical worker. Both the qualitative interviews and the participant observations meet the requirements of methods and data triangulation (Denzin 1978; 2012:82) and provided complex empirical material to understand mobbing group processes.

\section{Findings}

The findings presented in the paper are based on qualitative data analyzed with the use of ATLAS.ti
8.4.2 software. The key categories were generated inductively due to open and selective coding of 72 targets' narratives and 12 in-depth interviews with the specialists (Konopásek 2008; see also Strauss and Corbin 1990).

\section{Mobbing as a Social Process}

Mobbing never happens suddenly (Niedl 1996; European Working Conditions Survey 2015). It usually involves the offender(s) and target(s) over time long enough to change or alter their definitions of the situation (Leymann 1996). Typically, the situation is worsening gradually, day-by-day, and because of that a target may not perceive specific attacks as an interconnected whole.

It took me some time to realize that I have been mobbed. [teacher, female]

I was not aware of the fact that the problem was escalating. [financial expert, male]

The victims used to be "consistent" in terms of constantly defining the situation as an incidental conflict, periodically worse organizational climate, or long-lasting bad mood of the mobber. They tend to be "immobilized" when it comes to defining the worsening relationship between them and their offenders. Still, they try to keep in mind the picture of the situation, and thus-sometime later-discover their "new" positioning-that of the victim. I term the instances in which targets redefine their situation "turning points" (Strauss 1969). Redefining their situation and negotiating its definitions-that do not fit anymore to a more optimistic scenario they thought was likely to happen-is a crucial moment for them. Such "turning points" incline the targets to see themselves in victims' terms, with the "assistance" of of- 
fenders and more active bystanders. For mobbing at the workplace involves not only the perpetrator and their target, but also the audience who makes the process collectivistic and, at times, public.

\section{The Collectivism of Mobbing}

Mobbing often requires a denouncer, a target, and the audience, who are at times passive bystanders, happy that they are not in the target's shoes. In other cases, the target(s)' colleagues may take a more active part in their degradation process. These processes are based on collectively produced definitions of the situation and are a way of acting, that is, what Blumer (1969:71) called "joint action." The offenders, and sometimes bystanders, use degradation rituals (Garfinkel 1956) to ridicule, stigmatize, isolate, or otherwise humiliate the target (Klapp 1949). In the most extreme cases, their actions are focused on mortifying their targets in institutional settings (Goffman 1961:24-51; Scott 2010:219) and preventing them from an active defense. One of the mobbed police officers confirms the existence of a public ritual of degradation, where his supervisor played the role of the offender:

He did all of that intentionally to humiliate me in front of my colleagues. He was always satisfied afterward. [police officer, male]

A mobber is a person who both initiates the degradation ceremony and invites others to take an active part in it, or at least take the role of passive eyewitnesses. The witnesses' presence may serve to validate the offenders' attacks via a lack of support for the target, whom the offender may frame as a scapegoat. A factory worker confirms the role of a collectively constructed definition of the situation where fear of possible consequences prevented bystanders from offering a victim any support.
They just observed what was happening to me with no intention to react. They were afraid of their position, some of them were even laughing. [factory worker, male]

Public mobbing also involves emotional issues. A victim humiliated in front of their colleagues is "frozen," feeling ashamed enough not to react and fight back. Such a public scenario of mobbing practices is performed by an offender to scare away potential defenders. The message a mobber sends out is clear: "anybody can replace a victim, so take part and do not react." Thanks to that an offender symbolically multiplies their allies, and the dominance over a victim grows, which locates them in a position defined as irretrievable and defenseless (Leymann 1996:168). One of the teachers claimed being constantly at the center of such a degradation ceremony, headed by a school headmaster:

The other day, during the pedagogical council, she [the school headmaster] laughed at me and my work, publicly quoting my official notes from the school documents. It was awful. She publicly suggested that I should visit some psychologist or psychiatrist to verify my professional competences. [teacher, female]

\section{The Turning Point}

The turning point is a significant moment of identity transformation, when-under new circumstances-a person redefines the situation that they experience and change the conception of oneself (Strauss 1969:91). The victims interpret the turning point in terms of "awakening" from a long-lasting dream about work-related circumstances that are long outdated. Since that moment an employee defines oneself as a victim and usually initiates some form of action (e.g., seeking help, preparing a defense, collecting evidence). The turning point begins with the 
victim's mental preparation for taking an active part in changing the experienced situation, intending to seize the initiative.

At some point, I noticed that the manager started treating me worse than the others. I think the school I attended caused it. I asked the manager for some days off and once again she refused to give me them. [shopping mall employee, female]

Everything began when I was offered some better assignments-similar work, but better conditions. I took it with the hope that it will be my life accomplishment. Unfortunately, it turned out to be a horror. [private company accountant, female]

In some cases, the turning point also means the turning of a passive victim into an active opponent ready to change not only their position within the work settings but also the relationship with an offender. This process also assumes undertaking a long-lasting work on identity (Strauss 1969). Very often the target's significant others (family members, colleagues, friends) take on the role of those who initiate changes along the lines of interpreting the situation of a maltreated employee. Because of strong emotional bonds associated with significant others, they are often in a position of influencers and can help a victim to pass through the "turning point" and undertake the accompanying identity work.

It was my husband, with whom I talked a lot, who changed my point of view on my professional situation. [teacher, female]

Nevertheless, not all of the mobbing victims change their strategy after experiencing the "wake-up call." Some of them follow the trajectory of becoming a victim.

\section{The Trajectory of Becoming a Victim}

Mobbing targets who experienced the turning point and did not take any action-oriented steps focused on improving their situation very often experience the trajectory of becoming a victim. I adapted the concept of trajectory from Fagerhaugh and Strauss (1977) to depict the inert path of victims towards a passive position of a person who is not able to react (Leymann 1996; Zapf, Knorz, and Kulla 1996; Hoel, Faragher, and Cooper 2004). The trajectory of becoming a victim is linked with the process of social self-transformation, based on the interpretations that also include the others' definitions of the situation (James 1950:293; see: Cooley 1922:179; Mead; 1934:192). One of the victims underlined the crucial role of the looking-glass self (Cooley 1922:184) in self-definition mechanisms.

I felt like a victim and I was also the victim in the eyes of all of my colleagues. [office worker, female]

Victims used to be "frozen" in their self-definitions as passive members of a predefined situation where they were out of power to influence their relations in the professional settings (Prus 1999).

For a long time, I was the person who was not reacting. I couldn't even imagine that I could fight against it. [sales representative, male]

The trajectory of becoming a victim is a highly interactive phenomenon, greatly influenced by the looking-glass self (Cooley 1922:184). In their self-interpretation processes, the mobbing victims take into account the perspectives of others involved in the degradation ceremony (Garfinkel 1956), who are forcing them to accept the new status given by the group (Strauss 1969:77; Fagerhaugh and Strauss 1977:120). 
The trajectory path requires joint action where social actors adjust to each other (Blumer 1969:71) to create a coherent scenario (degradation ceremony) of the social exclusion of the target and to prepare them for living on the margins of the social world of the setting at hand. A victim, similarly to a deviant, does not have full rights and lives peripherally, negatively labeled by some audiences (Goffman 1963; Prus and Grills 2003).

A person under attacks may interpret their situation as both difficult and complicated enough to not seek help or change.

I didn't know what to do. It was like an ongoing nightmare with no place to hide and no way to escape. [sales representative, male]

Mobbing victims experiencing such a trajectory construct a specific mental representation of the professional environment, where all of the options are closed. They adopt a passive role in the organization and locate the control over the situation outside of themselves, and adopt a socio-psychological mechanism of closure to "resolve the tension initiated by the situation" (Lemert 1953:304). The victims use a long-lasting modus operandi based on resignation from any reaction against the offender to "close" the tension and redefine the situation. They also choose "not to act" through a social act of omission that leads to canceling, losing, and withdrawing from active participation in their professional environment (Scott 2019).

\section{Conclusions}

Mobbing is a joint action, rich in symbolic phenomena, that linguistically enables the involvement of people from one's professional environment. Of course, not everybody takes the role of the offender, but, in most cases, even bystanders involved in joint action have a great influence on the victim's interpretation of the situation. Usually, employees who suffer from mobbing at the workplace change their definition of themselves (identity) and their work-related surroundings. Those harassed at work are at the center of degradation ceremonies that very often involve both offender(s) and eyewitnesses to take part in such a scenario that imposes a new status (that of the victim) on the person under attacks. Offenders (and occasionally bystanders) engage in designating deviance via labeling that has the power to marginalize others due to assigning them the roles such as scapegoats (Goffman 1963). That language is rich in restricted codes that "reduce the need to verbalize intent so that it becomes explicit" (Bernstein 1971:100) and may become part of common knowledge shared by those within the target's professional environment.

The crucial moment in the victims' biographies is the turning point that divides mistreated employees into two groups: those who take the active role in breaking the mobbing cycle and those who apply a passive strategy and are not willing to fight. The victims ready to change their situation usually benefit from the support of significant others who are "waking them up." Thanks to family members, friends, and colleagues, the harassed employees may come to redefine the situation and adapt strategies to resist the domination approach of the mobber. Those who apply a passive strategy usually experience a trajectory of interactional sequences, which results in a rather encompassing victim identity.

\section{Acknowledgments}

The author wishes to thank Professor Krzysztof T. Konecki (University of Lodz) and the anonymous Reviewers for their helpful suggestions and debate. 


\section{References}

Anderson, Cheryl. 2002. "Workplace Violence: Are Some Nurses More Vulnerable?" Issues in Mental Health Nursing 23:351-366.

Athens, Lonnie. 2017. Domination and Subjugation in Everyday Life. London, New York: Routledge.

Auguste, Elizabeth, Ali Briggs, and Lee Vreeland. 2014. “Symbolic Interactionism and Bullying: A Micro-Sociological Perspective in Education." Journal of Cross-Disciplinary Perspectives in Education 7(3):10-19.

Bernstein, Basil. 1971. Class, Codes and Control. Theoretical Studies towards Sociology of Language. London: Routledge.

Biernacki, Patrick and Dan Waldorf. 1981. "Snowball Sampling. Problems and Techniques of Chain Referral Sampling." Sociological Methods E Research 10(2):141-163.

Blumer, Herbert. 1966. "Sociological Implications of the Thought of George Herbert Mead." American Journal of Sociology 71(5):534-544.

Blumer, Herbert. 1969. Symbolic Interactionism. Perspective and Method. Englewood, NJ: Prentice-Hall.

Bryant, Melanie and Julie W. Cox. 2003. "The Telling of Violence: Organizational Change and Atrocity Tales." Journal of Organizational Change Management 16(5):567-583.

Bryant, Melanie, Donna Buttigieg, and Glennis Hanley. no date. "Re-Defining Workplace Bullying: An Interactionist Approach to Exploring How Participants Frame and Define Their Experiences." Retrieved August 28, 2020 (https://www.anzam. org/wp-content/uploads/pdf-manager/1228_BRYANT_MELANIE-151.PDF).

Çelik, Kezban and Demet Lüküslü. 2012. "Spotlighting a Silent Category of Young Females: The Life Experiences of 'House Girls' in Turkey." Youth \& Society 44(1):28-48.

Chamberlain-Salaun, Jennifer, Jane Mills, and Kim Usher. 2013. "Linking Symbolic Interactionism and Grounded Theory Methods in a Research Design: From Corbin and Strauss' Assumptions to Action." SAGE Open July-September:1-10.

Charmaz, Kathy. 2014. Constructing Grounded Theory. A Practical Guide Through Qualitative Analysis. London: Sage.
Chomczyński, Piotr A. 2006. “Wybrane problemy etyczne w badaniach. Obserwacja uczestnicząca ukryta" [Selected Ethical Problems of the Research. Covert Participant Observation]." Przeglad Socjologii Jakościowej 2(1):68-87.

Chomczyński, Piotr A. 2008. Mobbing w pracy z perspektywy interakcyjnej. Proces stawania sie ofiara [Mobbing at the Workplace from an Interactionist Perspective. The Process of Becoming a Victim]. Lodz: Wydawnictwo Uniwersytetu Łódzkiego.

Chomczyński, Piotr A. 2017. “Emotion Work in the Context of the Resocialization of Youth in Correctional Facilities in Poland." Polish Sociological Review 2:219-235.

Cooley, Charles H. 1922. Human Nature and the Social Order. New York: Charles Scribner's Sons.

Corbin, Juliet and Anselm L. Strauss. 2008. Basics of Qualitative Research: Techniques and Procedures for Developing Grounded Theory. Los Angeles, CA: Sage.

Czarniawska, Barbara. 2007. “Narrative Inquiry In and About Organizations." Pp. 383-404 in Handbook of Narrative Inquiry: Mapping a Methodology, edited by D. Clandinin. Thousand Oaks, CA Sage.

Czekaj, Krzysztof. 2007. Socjologia Szkoty Chicagowskiej i jej recepcja w Polsce [Chicago School and Its Reception in Poland]. Katowice: Górnośląska Wyższa Szkoła Handlowa.

Denzin, Norman K. 1978. "The Research Act." In Symbolic Interaction. A Reader in Social Psychology, edited by J. Manis and B. Meltzer. Boston, MA: Allyn and Bacon.

Denzin, Norman K. 2012. "Triangulation 2.0." Journal of Mixed Methods Research 6(2):80-88.

Fagerhaugh, Shizuko Y. and Anselm L. Strauss. 1977. Politics of Pain Management: Staff- Patient Interaction. New York: Addison-Wesley Publishing Company.

Garfinkel, Harold. 1956. “Conditions of Successful Degradation Ceremonies." American Journal of Sociology LXI:420-424.

Glaser, Barney and Anselm L. Strauss. 1967. The Discovery of Grounded Theory: Strategies for Qualitative Research. New York: Aldine Publishing Company. 
Gobo, Giampietro and Andrea Molle. 2017. Doing Ethnography. London: Sage.

Godlewska-Werner, Dorota. 2006. "Mobbing w polskich przedsiębiorstwach [Mobbing in Polish Companies]." Zarzadzanie Zasobami Ludzkimi 1(46):43-56.

Goffman, Erving. 1961. Asylums: Essays on the Social Situation of Mental Patients and Other Inmates. Garden City, NY: Anchor Books, Doubleday and Co.

Goffman, Erving. 1963. Stigma: Notes on the Management of Spoiled Identity. Englewood Cliffs, NJ: Prentice-Hall.

Gusfield, Joseph R. 2003. "A Journey with Symbolic Interactionism." Symbolic Interaction 26(1):119-139.

Hallberg, Lillemor R-M. and Margaretha K. Strandmark. 2006. "Health Consequences of Workplace Bullying: Experiences from the Perspective of Employees in the Public Service Sector." International Journal of Qualitative Studies on Health and Wellbeing 10:109-119.

Hałas, Elżbieta. 1990. “Biografia a orientacja symbolicznego interakcjonizmu [Biographical Orientation of Symbolic Interactinism]." Pp. 197-208 in Metoda biograficzna w socjologii [Biographical Method in Sociology], edited by J. Włodarek and M. Ziółkowski. Warsaw, Poznan: PWN.

Hałas, Elżbieta. 1994. Obywatelska socjologia szkoły chicagowskiej [Civic Sociology of the Chicago School]. Lublin: Wydawnictwo KUL.

Hoel, Helge. 2004. "Violence and Harassment in European Workplaces: Trends and Political Responses." Pp. 8-12 in The Fourth International Conference on Bullying and Harassment in the Workplace, edited by S. Einarsen and M. B. Nielsen. Bergen, Norway.

Hoel, Helge, Brian Faragher, and Cary L. Cooper. 2004. “Bullying Is Detrimental to Health, But All Bullying Behaviours Are Not Necessarily Equally Damaging." British Journal of Guidance and Counselling 32(3):367-387.

Jacobson, Kathryn, Jacqueline Hood, and Harry Van Buren. 2014. "Workplace Bullying Across Cultures: A Research Agenda." International Journal of Cross Cultural Management 14:47-65.

James, William. 1950. The Principles of Psychology. New York: Dover Publications.
Jovchelovitch, Sandra and Martin W. Bauer. 2000. Narrative Interviewing. London: LSE Research Online. Retrieved January 27, 2019 (http://eprints.lse.ac.uk/2633).

Klapp, Orrin E. 1949. "The Fool as a Social Type." American Journal of Sociology LV:157-162.

Klunklin, Areewan and Jennifer Greenwood. 2006. "Symbolic Interactionism in Grounded Theory Studies: Women Surviving With HIV/AIDS in Rural Northern Thailand." Journal of the Association of Nurses In Aids Care 17(5):32-41.

Konecki, Krzysztof T. 2000. Studia z metodologii badań jakościowych. Teoria ugruntowana [Studies in the Methodology of Qualitative Research. Grounded Theory]. Warsaw: PWN.

Konecki, Krzysztof T. 2005a. "The Problem of Symbolic Interaction and of Constructing Self." Qualitative Sociology Review 1(1):68-89.

Konecki, Krzysztof T. 2005b. “Problem interakcji symbolicznej a konstruowanie jaźni [The Problem of Symbolic Interaction in Constructing of the Self]." Pp. 40-58 in Konstruowanie jaźni $i$ społeczenstwa [The Construction of the Self and Society], edited by E. Hałas and K. Konecki. Warsaw: Wydawnictwo Naukowe Scholar.

Konecki, Krzysztof T. 2015. “Anselm L. Strauss - pragmatyczne korzenie, pragmatyczne konsekwencje" [Anselm L. StraussPragmatic Roots, Pragmatic Implications]." Przeglad Socjologii Jakościowej 11(1):12-39.

Konecki, Krzysztof T. 2017. “Qualitative Sociology.” Pp. 143-152 in The Cambridge Handbook of Sociology. Core Areas in Sociology and the Development of the Discipline, edited by K. O. Korgen. Cambridge: Cambridge University Press.

Konecki, Krzysztof T. and Piotr A. Chomczyński. 2012. Słownik socjologii jakościowej [The Dictionary of Qualitative Sociology]. Warsaw: Difin.

Konopásek, Zdeněk. 2008. "Making Thinking Visible with Atlas.ti: Computer Assisted Qualitative Analysis as Textual Practices." Forum: Qualitative Social Research 9(2):Art. 12.

Lemert, Edvin M. 1953. "An Isolation and Closure Theory of Naive Check Forgery." The Journal of Criminal Law, Criminology, and Police Science 44(3):296-307.

Lemert, Edvin M. 1962. "Paranoia and the Dynamics of Exclusion." Sociometry 25(1):2-20. 
Leymann, Heinz. 1996. "The Content and Development of Mobbing at Work." European Journal of Work and Organizational Psychology 5(2):165-184.

Loch, Ulrike. 2008. "Traces of Traumatizations in Narrative Interviews." Forum: Qualitative Social Research 9(1):Art. 54.

Mead, George H. 1934. Mind Self and Society from the Standpoint of a Social Behaviorist. Chicago: University of Chicago Press.

Neuman, Joel H. and Robert A. Baron. 2003. "Social Antecedents of Bullying: A Social Interactionist Perspective." Pp. 185202 in Bullying and Emotional Abuse in the Workplace International Perspectives in Research and Practice, edited by S. Einarsen et al. London, New York: Taylor \& Francis.

Niedl, Klaus. 1996. "Mobbing and Well-Being: Economic and Personnel Development Implications." European Journal of Work and Organizational Psychology 5(2):239-249.

Piotrowski, Andrzej. 1985. “Osobowość a tożsamość. O pewnej tendencji we współczesnej socjologii interakcji [Personality and Identity. Something about the Contemporary Tendency in Sociology of Interaction]." Folia Sociologica 12:19-44.

Prus, Robert. 1999. Beyond the Power Mystique: Power as Intersubjective Accomplishment. Albany, NY: State University of New York Press.

Prus, Robert and Scott Grills. 2003. The Deviant Mystique: Involvements, Realities, and Regulation. Westport, CT: Praeger.

Salin, Denise et al. 2018. "Prevention of and Interventions in Workplace Bullying: A Global Study of Human Resource Professionals' Reflections on Preferred Action." The International Journal of Human Resource Management 1-23.

Scott, Susie. 2010. "Revisiting the Total Institution: Performative Regulation in the Reinventive Institution." Sociology 44(2):213-231.

Scott, Susie. 2019. The Social Life of Nothing: Silence, Invisibility and Emptiness in Tales of Lost Experience. New York: Routledge.
Strauss, Anselm L. 1969. Mirrors and Masks. The Search for Identity. San Francisco: Sociology Press.

Strauss, Anselm L. 1987. Qualitative Analysis for Social Scientists. Cambridge: Cambridge University Press.

Strauss, Anselm L. and Juliet Corbin. 1990. Basics of Qualitative Research. Grounded Theory. Procedures and Techniques. Newbury Park, CA: Sage Publications.

Thornberg, Robert and Hanna Delby. 2019. "How Do Secondary School Students Explain Bullying?" Educational Research 61(2):142-160.

Tracy, Sarah J., Pamela Lutgen-Sandvik, and Jess K. Alberts. 2006. "Nightmares, Demons, and Slaves Exploring the Painful Metaphors of Workplace Bullying." Management Communication Quarterly 20(2):148-185.

Wilson, Thomas P. 1970. "Normative and Interpretive Paradigms in Sociology." Pp. 57-70 in Everyday Life: Reconstruction of Social Knowledge, edited by J. D. Douglas. New York: Routledge.

Wojciechowska, Magdalena. 2018. “Doing Research on Behind-the-Scenes Phenomena: Entering the Female Escort Industry." Pp. 133-143 in The Craft of Qualitative Research, edited by S. W. Kleinknecht, L-J. K. van den Scott, and C. B. Sanders. Toronto, Vancouver: Canadian Scholars' Press.

Woroniecka, Grażyna. 2017. “Co znaczy 'rozumieć' w 'perspektywie i metodzie' interakcjonizmu symbolicznego Herberta Blumera? [What Does It Mean 'to Understand' in Herbert Blumer's 'Perspective and Method' of Symbolic Interactionism?]." Roczniki Nauk Społecznych 8(44):51-66.

Zapf, Dieter, Carmen Knorz, and Matthias Kulla. 1996. “On the Relationship between Mobbing Factors, and Job Content, Social Work Environment, and Health Outcomes." European Journal of Work and Organizational Psychology 5(2):215237.

\section{Citation}

Chomczyński, Piotr A. 2020. "Mobbing from the Standpoint of Symbolic Interactionism." Qualitative Sociology Review 16(4):52-62. Retrieved Month, Year (http://www.qualitativesociologyreview.org/ENG/archive_eng.php). DOI: http://dx.doi. org/10.18778/1733-8077.16.4.04 